\title{
CHINA'S GLOBAL CONQUEST FOR OIL: A RESEARCH REVIEW OF CHINESE ODI
}

\author{
A. Kilani \\ Peoples' Friendship University of Russia (RUDN University) \\ Miklukho-Maklaya str., 6, Moscow, Russian Federation, 117198
}

\begin{abstract}
With all natural resources at its possession and the ambition to conquer the globe, China has set its role as one of the biggest international players in the world economy. Considering liberalized policies recently employed by China, it was just a matter of time before the country shifted from being a communist state to becoming a capitalist economy. The effect of China's 'going out' policy is remarkable in both developing and developed nations. China has become a phobia for western countries, especially the United States, imposing a threat for their state enterprises which cannot sustain the competition, and a lifesaver for those trying to improve their living standards. This paper will review six articles on China's outward direct investment (ODI), its formation and effect on other states.
\end{abstract}

Key words: oil, China, outward direct investment (ODI), Chinese National Oil Companies (NOCs)

The modernization of China's petroleum industry has been fostered greatly by price liberalization, competition, enterprise reform, and management incentives. Although China vigorously fortified foreign investment in the past, enterprises are currently playing the central role, shaping policy domestically and internationally to suit the country's economic interests. China's outward direct investment (ODI) has experienced a significant increase since the 1990s. After 2002, when China started its 'Going Global' plan to encourage its foreign investment activity, China's ODI surged remarkably. Between 2003 and 2009, China's ODI increased nearly sevenfold, from \$33 billion to $\$ 230$ billion. 2016 was the strongest year for Chinese ODI on record, with ODI flows outstripped foreign direct investment (FDI) for the first time [2. P. 5]. China is the second largest oil importer after the United States, and it is expected to take the lead in the next few years. China's large oil consumption is creating many issues for the government. Beijing considers oil a national security issue and, in order to survive, China is prepared to come face-to-face with the western hemisphere, especially the USA, in a battle for oil.

This paper will examine six articles that review the origin of China's outward direct investment, mainly in oil, and discuss the consequences of Chinese ODI in several countries. These articles focus on different aspects related to the matter at hand. The first article presents an overview of China's outward direct investment [6]. The second one examines the history of Chinese ODI, the diametrically opposed reactions of the United States, and the challenges faced by Chinese multinational corporations operating in or attempting to enter the U.S. market [3]. The third article traces the development of China's ODI policies and presents some findings from a recent survey on Chinese outward investment intentions in Canada [8]. The fourth article focuses on the developing 
world and analyzes Chinese ODI in Africa [1]. After an overview of the countries affected by Chinese ODI, the fifth article presents a brief analysis of the confluence of domestic factors, both economic and political, that shape the behavior of National Chinese oil companies (NOCs) abroad and the implications of this behavior for energy security in China and the rest of the world [4]. Finally, the sixth article looks at the acquisitions of well-known international firms by Chinese companies [7]. By means of reviewing the mentioned articles, this paper will trace the origin of Chinese ODI, evaluate its role in U.S, Canada, and Africa, and discuss the Chinese National Oil Companies' (NOCs) strategies and motivations. The articles in question were selected from reliable scientific journals writing about Chinese political and economic affairs. Among the publishers are the Hong Kong Institute for Monetary Research, U.S.-China Economic $\&$ Security Review Commission, and Project Muse. The authors' expertise ranges from policy analysis to academic work in the field of political economy.

\section{OVERVIEW OF CHINA'S ODI AND ITS IMPLICATION FOR THE U.S ECONOMY}

We will start the analysis of China's outward FDI (foreign direct investment) by reviewing the article "Going Out: an Overview of China's Outward Foreign Direct Investment" by Nargiza Salidjanova [6]. In her analysis, the author points out four main trends in the development of ODI in China. First, Chinese outward FDI is growing with a rapid pace; since China has considerable savings, it invests mainly in low-yield treasury bonds, however, the Chinese are seeking to diversify their assets and looking into high-yield bond investing. Second, Chinese ODI is widely spread in small amounts; the author gives empirical evidence demonstrating that Chinese investments are spread over 177 countries and can be as low as $\$ 10,000$ per sector. Third, China is heavily involved in Merger and Acquisition policy (M\&A), i.e. Chinese companies invest in and bid for other companies in the developed world. Salidjanova gives the example of CNOOC's failed bid for Unocal in 2005. Finally, Chinese investments are directed by the government via government executives inside companies, especially in the energy and communication sectors; in return, the government provides a variety of subsidies including low interest rate loans from major banks, which are publicly owned. Salidjanova's analysis has four sections: 1. Evolution of China's outward investment and organizational background; 2. Distribution of China's ODI by destination and type; 3. Round-tripping of Chinese investments; 4. Future of Chinese direct investment and U.S interests.

In the first section, Salidjanova states that ever since the Chinese government initiated foreign investment, it has retained tight control over its development and makes major decisions, such as what type of industries to invest in and which markets to expand to, thus aligning foreign investment with the government's long-term development strategies. China's ODI has gone through four stages of development. The first stage was between 1979 and 1985, when trade and investment were controlled solely by the government. During the second stage (1986-1991), the government allowed non-state enterprises to invest overseas. The third stage was between 1992 and 1998, during which liberalization continued but many countries suffered heavy losses 
due to corruption and institutional weakness (the author must be referring to the Asian Economic Crisis), and as a result, ODI activities leveled off, yet continued to increase slightly. The last stage (1999 — present) marks the beginning of China's "going out" policy aimed at promoting "the international operations of capable Chinese firms with a view to improving resource allocation and enhancing their international competitiveness". Moreover, China had other rational reasons to initiate their "going out" policy: mainly to access and secure overseas supply of new resources due to dramatic increase in domestic demand for raw materials, especially in the energy field. Another reason is the acquisition of advanced technology: Chinese companies are actively purchasing foreign firms, such as IBM's personal computer division, to access state-of-the-art technologies and manufacturing processes.

Next, Salidjanova discusses the distribution of Chinese ODI by destination and type, supporting her argument with empirical data. The author explains that most of China's ODI is concentrated in Asia and the Middle East (75.5\%); nevertheless, the flow of Chinese ODI in the United States has been experiencing notable increase. The author presents an ODI diagram, showing investment distribution by sectors, the highest percentage of investment flow being in the services sector, which attests to the fact that Chinese companies are set on serving and promoting the export of Chinese commodities. The energy sector is the third biggest and is most important for China. Salidjanova shows this clearly by giving examples of Chinese NOCs buying other oil companies as part of China's merging and acquisition policy.

In the last section, the author writes about China-U.S relations and the impact of China's ODI on American Economy and interests. In short, Salidjanova believes that Chinese enterprises present a problem for developed countries since they are state owned and lack transparency, not to mention the fact that they create zero employment, since Chinese companies tend to bring employees from China. Overall, the author's speculation is that Chinese ODI will continue to grow due a number of reasons, such as high demand for raw materials, purchase of new technology, merger and acquisition policy, and access to natural resources.

\section{CHINESE ODI IN THE UNITED STATES}

After the general overview of China's ODI, we will proceed to analyze the effect of Chinese FDI on the United States' economy by reviewing the article "China's Outward Foreign Direct Investment" by Wei He and Marjorie A. Lyles [3]. The authors argue that China's direct investment in the United States is economically, not politically, driven; they support this argument by referring to the phenomenon they call "China fever vs. China fear" - the response of American public which falls at opposite end of the spectrum. He and Lyles state that Chinese FDI in the United States is being welcomed by the majority of U.S governors, who solicit Chinese companies to invest in their states; however, the takeover of American businesses by Chinese companies has caused fear and raised national security concerns. In addition, the authors explore the challenges of Chinese Multinational Corporations (MNCs), their opportunities in direct investing in the United States, their lack of experience in foreign investment and its political consequences. 
He and Lyles trace the "China fear vs. China fever" phenomenon back to China's entrance into the WTO, which made investing in China particularly attractive for American companies due to low cost labor and the largest consumer market in the world (1.3 billion customers). The authors mention that more than twenty American States have established commercial offices in China; therefore, they see China as a business partner regardless of the country's communist regime. On the other hand, fear of China grows due to its rapidly increasing influence in the international arena. Hence, Americans are afraid of Chinese political and economic takeover, as they believe that the U.S. is losing its manufacturing base to China, which may result in trade imbalance in the United States. Other fears relate to national security, health and safety matters, as Chinese manufacturers have been neglecting safety measures and producing goods of poor quality. A growing distrust of China is also related to violation of intellectual property rights. Overall, China's fast growing investment in the United States and acquisition of major U.S companies constitute a cause for concern. The authors refer to a similar situation in the 1980s, when Japan acquired a number of U.S businesses, which raised cultural and political fear. As for the fear of competition, the authors believe it is mostly unfounded, since Chinese companies are state-owned and do not have to make any profit. Since the 1990s, Chinese companies have become less controlled by the state and are required to make profits to be distributed among the shareholders, the government being one of them. At the end of this section, the authors note that China is still a developing country whose economy is in the transition phase, and it is facing difficulties related to certain legal issues, for example, copyrights.

In the next section, he and Lyles talk about the roots of Chinese FDI in the United States. According to the authors, 2005 was a remarkable year for the development of Chinese ODI in the United States: they talk about the acquisition of IBM's personal computer department by Lenovo and the takeover bid for Maytag by Haier. However, the authors mention that Chinese investment in the United States goes back to 1981, after China's "reform and opening up" policy was initiated. The most notable occurrence was when a Chinese bank opened its branch in New York; currently it is a fully operating retail and commercial institution. There was also a number of other buyouts of American companies by Chinese firms in several industries, in addition to China opening industries in the States. The authors then proceed to talk about the "Liability of Foreignness" and point out four sources of costs that firms operating overseas have to incur: increased operating costs caused by spatial distance, firm-specific costs related to the unfamiliarity with the culture of the local market, costs resulting from the host country's political and economic characteristics, and costs derived from the home country environment. However, the authors present a counter argument claiming that some of these liabilities can be managed, such as spatial distance, which can be facilitated by mutual agreements. As for cultural differences, although Chinese firms have learned how Americans run their businesses in China, the cross-cultural collaboration still needs time to develop. The problem of cultural misunderstanding is demonstrated using the example of Haier, when some of the Chinese company's methodologies had to be altered in order to correspond American values. The authors believe that while it took more than two decades for American companies to adapt and integrate in China, Chinese companies in the States 
will assimilate in less than twenty years. At the end, the authors suggest that Chinese firms should avoid investing in sensitive industries, such as energy and defense, as it may become a matter of national security. They also add that China's economy will surpass U.S. economy in the next twenty to thirty years with 60 per cent growth in ODI.

\section{CHINESE ODI IN CANADA}

To get a better understanding of China's investment relationships with other developed countries, we will review the article "China Goes Global: The Implications of Chinese Outward Direct Investment for Canada" by Yuen Pau Woo and Kenny Zhang [8], which focuses on Chinese investment policies in Canada. The authors pay close attention to developed countries' concerns related to Chinese investment, as most industrialized nations feel apprehensive about giving China access to their technological and natural resources. Besides, China has had bad reputation as a notorious human rights violator. Further, the article traces the development of Chinese ODI policies, and discusses the current state of Chinese FDI in Canada.

Woo and Zhang point out that Chinese ODI is highly regulated and was primarily driven by government interests until the recent 'going out' policy announced by the regime in 2002. The authors divide Chinese ODI policy into five stages. The first stage lasted from 1979 to 1983 , when the only firms allowed to invest overseas were stateowned and approved by the State Council. During the second stage (1984-1992), ODI was liberalized and non-state enterprises were permitted to establish foreign subsidiaries. The third stage (1993-1998) is described by the authors as one marked by greater control of overseas investment; the government introduced rigorous policies for monitoring ODI to ensure the investments are being productive. The fourth stage (19992002), heralded by China's entry into the WTO, was a turning point in Chinese ODI policy, as the government encouraged national enterprises to engage in global trade and production. The fifth (current) stage started in 2002 at the Chinese Communist Party's $16^{\text {th }}$ Congress, when the leadership announced its famous 'Stepping Out' policy and urged Chinese companies to move from exporting to investing overseas. The authors note that recent changes in ODI policy have focused on five main areas: creating incentives for ODI; streamlining administrative measures, including greater transparency of intentions and decentralization of government authority; reducing investment risks; providing investment guidance; and easing capital control. Woo and Zhang surmise that the current trend towards liberalization in Chinese ODI policy is likely to continue and they further compare China of 1980 to China of today, drawing parallels on how the decision-making authority was delegated from the central government to local governments, and eventually to the enterprise itself. Also they believe that the motivation for foreign investment has shifted from a mere interest in securing natural resource supply to gaining access to brands, markets, and technology.

The authors also present a survey analyzing the ODI intentions of Chinese companies. According to its findings, $23 \%$ of companies intend to raise their ODI within one year and more than $40 \%$ intend to invest overseas within next 2 to 5 years. As far as the motivation for ODI is concerned, the survey result suggests that the majority of 
companies consider business potential their primary motive, as opposed to following government's incentives and policy. Despite the fact that most of the largest overseas investment companies are state-owned, the survey found that many small and mediumsized privately owned companies are also stepping out into the global arena. Moreover, the survey shows that $60 \%$ of existing ODI is carried out through joint ventures, as Chinese companies see more potential in this type of investment. The top target industries for Chinese companies are in auto manufacturing, food, and electrical machinery. Woo and Zhang present statistics on Chinese investment in Canada, which is steadily increasing, while Chinese companies are buying Canadian shares mainly in the oil and energy sector.

Lastly, Woo and Zhang predict increase of Chinese ODI and further evolution of its liberalization policy. As for investment in Canada, the survey shows that only $8 \%$ of respondents would consider placing their subsidiaries in this country. Moreover, $40 \%$ of respondents did not have a basic knowledge of investment opportunities in Canada. Among the most promising sectors for investment in Canada, Chinese companies named ICT and energy, as shown by the survey. It is not clear why Chinese enterprises do not see Canada as a promising investment opportunity, however, the authors mention that certain initiatives are being taken on local, business, and governmental levels to encourage Canadian investment.

\section{CHINESE ODI IN AFRICA}

This section of the paper will discuss Chinese FDI in developing countries as opposed to the industrialized world, reviewed in the previous sections. Hence, we will turn to analyzing the article "China's Outward Direct Investment in Africa" by YinWong Cheung, Jakob de Haan, XingWang Qian and Shu Yu [1]. In this article, the authors examine China-Africa relations and present data and empirical determinants of Chinese ODI in Africa, which we are not going to touch upon since a detailed economic analysis is not our goal. The authors analyze China's ODI and find it relatively small in comparison with the world FDI. However, they note a substantial increase of China's ODI in developing countries, mainly Africa. They also talk about two academic opinions regarding Chinese ODI. The proponents of the first standpoint argue that Chinese investment in Africa has had a negative effect on the country's politics and economy, resulting in a setback of the political reform, crowding African industries, and worsening employment conditions. Advocates of the second point of view see a positive effect of China's growing engagement in Africa, including growth of African exports, development of infrastructure, increase in productivity, and improvement of the living standards of the Africans. In their investigation, the authors use both the officially approved ODI dataset (1991-2005) and a relatively new IMF format ODI dataset approved by the Ministry of Commerce of China.

The authors trace the establishment of China-Africa relations back to 1955, when China made its first contact with Egypt, offering its support to liberation movements and held the Bandung Asian-African conference in Indonesia. Subsequently, in the 1980s, China changed its role in Africa and began to cultivate economic ties and encourage 
business cooperation. According to data offered by the authors, China held diplomatic relations with 49 out of 54 African countries, with direct subsidiaries in 48 countries out of the 49. Ever since the "Going Global" policy was adopted, China has been establishing special economic zones in African countries with the goal to promote its manufacturing sector and create employment in Africa. As for the financial sector, China has been working in two major directions: facilitating China's economic activities in Africa by providing trade credits and investment loans; and creating a private equity fund to finance China's ODI in Africa (the China-Africa Development Fund). Analyzing trade relations between China and Africa, the authors mention that trade between the two had experienced a staggering growth in the new millennium, from $\$ 9.5$ billion in 2000 to $\$ 79.8$ billion in 2009 . Other cooperation includes contracts engaging China in African infrastructure, from building highways to constructing dams and energy plants. Overall, the authors believe that since China increased its involvement in Africa in the 2000s, the continent has witnessed significant economic improvement. However, the authors mention that western investors have been expressing their dissatisfaction with China's tendency to separate business from politics, as they can no longer put development incentives on African countries, while China benefits economically at the expense of democracy and human rights.

In the data and empiric section, the authors use three econometric methodologies, which will not be discussed in this paper excluding the results. In terms of output, the authors highlight that China seeks large markets measured by the GDP to place its investments, and that most African countries which have contracts with China will probably receive funds. As for the risk factor, the findings showed that Chinese investments are encouraged in countries with high corruption and criminality. Another ODI motive driving China to Africa is getting access to the continent's natural resources, especially oil and minerals; this is a relatively recent phenomenon, which became prominent after the adopted "Going Out" policy. In addition, according to the authors, this policy is the major, if not the sole, motive behind seeking resources in Africa. In general, the authors consider China-Africa relations to be based on equal partnership and call it a win-win strategy.

\section{THE STRATEGY AND EXECUTION OF CHINESE NATIONAL OIL COMPANIES (NOCS)}

To explain how Chinese ODI works, we need to get into more detail on NOCs' relationship with the government, their motives, strategies, and how they operate. In this context, we will review the article "The Roots of Chinese Oil Investment Abroad" by Trevor Houser [4]. The author traces the evolution of the Chinese oil sector, examines NOC-government relationship, and studies Chinese oil companies' motives, strategies and behavior overseas. As is stated by Houser, China's oil conquest started with massive natural resource depletion in China in the late 1970s. That, along with the inability to produce oil domestically, triggered a significant shift in Chinese oil policy in the early 1980s, when Beijing converted its petroleum and chemical ministries into state-owned enterprises: CNOOC and Sinopec. These enterprises were given authority to regulate Chinese oil policy; CNOOC, among other tasks, assumed responsibility for offshore 
oil exploration. The rest of Chinese oil companies joined in with CNPC in 1988. The three enterprises (CNOOC, Sinopec and CNPC) remained under the authority of the state planning commission, which entailed additional costs and possible structure reforms. According to Houser, there are a few ways for the government to control these enterprises: by imposing regulations, by assuming ownership (the government became the official owner of the companies) and hiring their own representatives to run the companies' business (the majority of the companies' executives are public administrators, for example, vice ministers). Therefore, as the author points out, National Oil Companies, had their own reasons to support the "going out" policy. At first, Sinopec and CNOOC were tasked to drill domestically, but could not afford to make a marginal profit due to price limitations. They tried to lobby the government to raise prices; the latter refused to do so, as it was fraught with high inflation in the energy sector and, as a result, national inflation. Therefore, the NOCs were forced to decrease their extraction and refining in order to cut losses, which led to a drop in Chinese oil reserve to below $1 \%$ and decrease in China's oil consumption to $9 \%$ globally. It became a national security issue for the Chinese government to supply oil and gas to its market, and it announced "going out" policy, while still encouraging domestic extractions.

After they "stepped out", the NOCs had to take into consideration certain aspects of offshore oil extraction: technical capabilities, competition from International Oil Companies (IOCs), and political risks. Chinese companies were rapidly expanding, which allowed them to sell their oil not only domestically, but in the global market as well. Drilling oil in areas of political instability, such as Africa, represented a certain risk for Chinese NOCs. However, they took full advantage over other IOCs and pulled oil in countries such as Iran, Sudan, and Syria; which, for certain political reasons, were inaccessible for western companies. Houser mentions another beneficial circumstance that helped Chinese NOCs' expansion: owned by the government, they do not need external financing, as they are not required to pay dividends to their stakeholders, unlike other International Oil Companies. The author mentions the case of Unocal buyout attempt, when CNOOC placed a topping bid for American oil company Unocal; the attempt to purchase Unocal fell through, however, it doubled CNOOC's subsidiary revenue. Houser also gives multiple examples on how Chinese companies benefit from governmental loans to third world countries, particularly Africa, which gives them drilling advantages over other oil companies. In his article, the author demonstrates contradictory relationships between the government and NOCs: one the one hand, oil companies have governmental support, as they share mutual goals (Houser mentions Angola loan as an example), on the other hand, and in majority of cases, their interests conflict (domestic fuel price example). The author elaborates on NOCs' strategies and behavior overseas, as well as the motives behind the NOCs offshore oil production and shows how it relates to national security issues.

\section{CHINESE COMPANIES' MAJOR ACQUISITIONS}

The last section of the review will deal with the M\&A activities of Chinese oil companies. The article "Global Ambitions: Chinese Companies Spread Their Wings" by Margot Schüller and Anke Turner [7] will help us to gain some insight on the topic. 
The article in question analyzes the development of China's overseas investment (which has already been discussed in great detail in our review), international merger and acquisition (M\&A) policy, the role of the government in the "going out" policy, Chinese companies' quest to become global players, and, finally, the future of China's ODI. In the first section, the authors present their overview of Chinese ODI history. Briefly, they state that Chinese ODI is rapidly increasing due to policy liberalization, and China is becoming an important source of FDI, ranking second to the United States, although China's current ODI is still relatively small. Consequently, they explain how China's main interest shifted from securing their natural resources to obtaining cutting edge technology and going global.

The second section of the article is of particular interest for the current review. Schüller and Turner mention that, according to the Ministry of Commerce in China, the share of M\&A was only $18 \%$ of China's total overseas investment. The main strategy in Chinese M\&A policy was purchasing well-known foreign companies. The authors put outward direct investments into two categories: investments in new assets and investments in existing assets. Building the facilities from scratch, which is referred to as a "greenfield investment", represents the first category; whereas M\&A belongs to the second category of ODI. The authors note that M\&A does not only have to deal with acquisitions, but also takeovers, buyouts, and consolidations. The main M\&A target of China is in North America and Asia, with investments in natural resources having the highest priority. The authors conclude this section with a rather unoriginal statement that China's M\&A (just like overall ODI) is still relatively small but is steadily increasing.

In the third section, Schüller and Turner look at the policies supporting the "going out" strategy, discussed earlier in this paper. Their review, like the previously analyzed articles, goes over the five stages of China's ODI development, from the 1980s to 2002. They also talk about the government's interest in offshore natural resources and the advantage of Chinese oil companies over their western counterparts, as they are not required to make any profit. Another reason for China's ODI growth is the necessity to explore new foreign markets due to China's expanding exports. Schüller and Turner delve into detailed explanation of the reasons why Chinese companies seek natural resources, the only legitimate reason being the government's involvement in the companies' decision making. The most significant M\&A activity can be considered CNOOC's bidding for Unocal in 2005; the bid topped the one offered by American company Chevron (18.5 billion to 16.5 billion), which was possible due to CNOOC's access to cheap loans from state-owned banks; however, Unocal was eventually merged with Chevron. Another important M\&A event is Haier's takeover of American company Maytag, which was seen by the Chinese as a way to penetrate the USA and EU's markets and to expand its product range. Besides Beijing's main M\&A goal of expanding into new markets, China still seeks acquisition of new technologies and brands. As for the future of China's ODI, the authors' conclusion is concurrent with the ones drawn in the other articles; although, they do establish co-relation between the increase of M\&A and that of the ODI. 


\section{CONCLUSION AND REMARKS}

In the articles reviewed, the discussion was centered around Chinese ODI policy reforms in the period from the 1980s to present, during which China changed its political regime from communist to capitalist. All the authors, except Salidjanova, mark 2002 as the year when 'going out' policy was launched, following years of economic and political liberalization. The major motivating factor for initiating this policy was China's desperate need for energy and natural resources. This need remains today and will remain in the future [5]. Subsequently, due to the liberalization of national enterprises, this need was fortified by seeking access to advanced technologies and western brands. 'Going Global' had many positive effects on China's economy, as well as the economies of other nations, for example, China's ODI played a key role in improving living standards in Africa, which was possible due to China's policy of non-involvement into the host country's internal affairs, as China it did not impose any conditions of African countries, unlike its western counterparts. In fact, African countries were more than willing to let China invest in their natural resources. However, the fear of Communist China's growing power prompted the leaders of developed countries to try and limit China's influence on the world economy and politics. The Chinese are very eager to acquire American companies to access state-of-the-art technology and open new markets. However, the United States, contrary to its democratic image, keeps attempting to slow the expansion of the Chinese oil market, as it did when U.S. Congress interfered in the bid of Unocal by CNOOC and did not allow the acquisition of the company by China. This demonstrates Washington's fear for their national security. As far as other developed countries are concerned, they encourage Chinese investments. A good example would be Canada: in their article, Yuen Pau Woo and Kenny Zhang present enough evidence to prove and highlight the importance of Chinese capital for the Canadian economy. Therefore, we can conclude that China's real competitor is not the developed world, but the global economic and political hegemony: United States and its main partners. Despite Chinese ODI still being relatively moderate, the articles reviewed show evidence that Chinese foreign investment will continue to grow and, eventually, change the distribution of power on the global arena.

\section{REFERENCES}

[1] Cheung Y.-W., de Haan J., Qian X.W., Yu Sh. China's Outward Direct Investment in Africa. Hong Kong Institute for Monetary Research; 2011: 1-38.

[2] China Going Global Investment Index 2017. A Report by The Economist Intelligence Unit. 2017. $33 \mathrm{p}$.

[3] He W., Lyles M.A. China's Outward Foreign Direct Investment. Business Horizons; 2008: 1-7.

[4] Houser T. The Roots of Chinese Oil Investment Abroad. Asia Policy. 2008; 5: 141-166.

[5] Oil 2018. International Energy Agency Report. Available from: https://www.iea.org/oil2018/. Accessed: 10.07.2018.

[6] Salidjanova N. Going Out: An Overview of China's Outward Foreign Direct Investment. U.S.-China Economic \& Security Review Commission. 2011: 1-41.

[7] Schüller M., Turner A. Global Ambitions: Chinese Companies Spread Their Wings. CHINA Actuel. 2005; 4: 1-12. 
[8] Woo Y.P., Zhang K. China Goes Global: The Implications of Chinese Outward Direct Investment for Canada. (n.d.). Available from: https://www.researchgate.net/publication/237429620 China_Goes_Global_The_Implications_of_Chinese_Outward_Direct_Investment_for_Canada. Accessed: $10.07 .20 \overline{18}$.

\title{
ГЛОБАЛЬНОЕ ЗАВОЕВАНИЕ НЕФТИ: ИССЛЕДОВАНИЕ ВНЕШНИХ ПРЯМЫХ ИНВЕСТИЦИЙ КИТАЯ
}

\author{
А. Килани \\ Российский университет дружбы народов \\ ул. Миклухо-Маклая, 6, Москва, Россия, 117198
}

\begin{abstract}
В статье утверждается, что, усиливая внешнеэкономическую экспансию, Китай определил свою роль в качестве одного из крупнейших международных игроков в мировой экономике. С момента начала политики экономической либерализации в стране переход к капиталистической экономике стал лишь вопросом времени. Эффект политики «выхода за рубеж» Китая отчетливо заметен как в развивающихся, так и в развитых странах. Автор полагает, что высокая инвестиционная активность КНР, в том числе и внешние прямые инвестиции, стали своеобразной фобией для западных стран, особенно для США, создавая угрозу для государственных предприятий, которые не могут выдержать конкуренции. В статье рассмотрены и проанализированы шесть аналитических статей о внешних прямых инвестициях Китая в нефтегазовой сфере, их формировании и влиянии на другие государства. На основе проведенного сопоставительного анализа автор делает вывод о том, что основным мотивирующим фактором для начала политики «выхода за рубеж» была острая потребность Китая в энергоносителях и природных ресурсах. Внешние инвестиции КНР будут продолжать расти, что, в конечном счете, изменит распределение сил на мировой арене.
\end{abstract}

Key words: нефть, Китай, внешние прямые инвестиции (ODI), национальные нефтяные компании Китая (ННК)

\section{Сведения об авторе:}

Ахмад Килани - аспирант кафедры сравнительной политологии Российского университета дружбы народов (ORCID ID: 0000-0002-5438-9264) (e-mail: ahmad.kilanys@gmail.com).

Information about the author:

Ahmad Kilani - Postgraduate Student of the Department of Comparative Politics, Peoples' Friendship University of Russia (RUDN University) (Russian Federation) (ORCID: 0000-0002-5438-9264) (e-mail: ahmad.kilanys@gmail.com).

Статья поступила в редакцию 27.07.2018.

Received 27.07.2018.

(c) Килани А., 2018. 